\title{
Asymmetric synthesis of (S)-2,6-dimethylchroman-4-one
}

\author{
Kevin J. Hodgetts*
}

Department of Chemistry, University College Dublin, Belfield, Dublin 4, Ireland Present address: Neurogen Corporation, 35 Northeast Industrial Road, Branford, CT 06405, USA

E-mail: khodgetts@nrgn.com

This paper is dedicated to Professor B. S. Thyagarajan

(received 25 Mar 02; accepted 22 Apr 02; published on the web 30 Apr 02)

\begin{abstract}
The asymmetric synthesis of (S)-2,6-dimethylchroman-4-one (3) is described. An intramolecular Mitsunobu cyclization to the desired (S)-2,6-dimethylchroman-4-one was employed as the key step.
\end{abstract}

Keywords: Chromanones, (S)-2,6-dimethylchroman-4-one, intramolecular Mitsunobu cyclization, stereocontrolled route

\section{Introduction}

The chroman-4-one (2,3-dihydro-4-oxo-4H-1-benzopyran) ring system occupies an important position among oxygen heterocycles and features in a wide variety of compounds of biological and medicinal interest. ${ }^{1}$ It occurs naturally with a variety of substituents at C-2. Examples include the antibiotic LL-D253a (1), ${ }^{2}$ the flavanone pinostrobin (2) ${ }^{3}$ and the plant product $(S)$ 2,6-dimethylchroman-4-one (3). ${ }^{4}$ In addition, many biologically active natural products containing a chroman ring system have been synthesized via 2-substituted chroman-4-one intermediates, including $\alpha$-tocopherol (vitamin E) (4). ${ }^{5}$

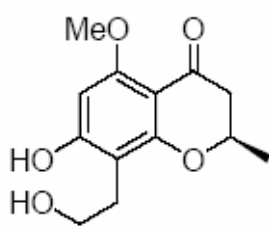

1



2<smiles>Cc1ccc2c(c1)C(=O)C[C@@H](C)O2</smiles>

3

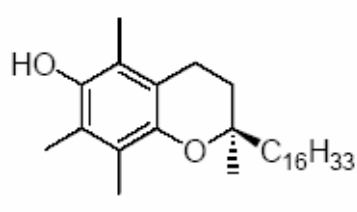

4

Stereocontrolled routes to 2-substituted chromanones are few in number. Successful examples include the diastereoselective conjugate addition of cuprates to homochiral 3-( $p$-tolyl- 
sulfinyl)chromanones ${ }^{6}$ and an approach based on the Houben-Hoesch reaction. ${ }^{7}$ Approaches to related 2-substituted chromans, ${ }^{8}$ chromenes, ${ }^{9}$ and chromanols $^{10}$ have also been reported. Notwithstanding these examples, the preparation and manipulation of substituted chroman-4ones can be problematic, due in part to the ease with which they undergo racemization via the ring opening equilibrium shown in Scheme $1 .{ }^{11}$ With this in mind, we have been evaluating the potential of approaches to 2-substituted chromanones based upon both inter- and intramolecular Mitsunobu reactions. ${ }^{12}$ In this paper we describe the application of the Mitsunobu cyclization to the synthesis of (S)-2,6-dimethylchroman-4-one (3), which has been isolated from the essential oil produced by natural roots (and also from genetically transformed root cultures) of Leontopodium alpinum (Edelweiss). ${ }^{4}$

<smiles>[B]C1Oc2ccccc2C([O-])=C1C</smiles><smiles>[B]C=C(C)C(=O)c1ccccc1[O-]</smiles>

\section{Scheme 1}

\section{Results and Discussion}

Commercially available ethyl (R)-3-hydroxybutyrate $(5)^{13}$ was protected as the TBS ether which was then converted into the Weinreb amide 6 using standard conditions (Scheme 2). ${ }^{14}$ Addition of two equivalents of lithium o-lithium-4-methylphenoxide (prepared from 2-bromo-4methylphenol and two equivalents of ${ }^{n} \mathrm{BuLi}$ ) to the amide 6 gave the ketone 7 in $74 \%$ yield (based on 6). The TBS protecting group was removed by treatment with $10 \% \mathrm{p}-\mathrm{TsOH}$ in aqueous THF and gave the alcohol 8 in $81 \%$ yield. Exposure of 8 to Mitsunobu conditions ${ }^{15}$ ( 1 equivalent of triphenylphosphine and diethyl azodicarboxylate in THF at $0{ }^{\circ} \mathrm{C}$ ) resulted in smooth cyclization to the chromanone (-)-3. A minor by-product was identified as the elimination product $9,{ }^{16}$ which was isolated in $7 \%$ yield. The spectral data for our synthetic sample of $\mathbf{3}$ was similar to the reported data for the natural sample, ${ }^{4}$ however, our material was crystalline (as opposed to an oil) with a specific rotation of the correct sign but more than double the magnitude of that reported. (S)-2,6-Dimethylchroman-4-one (3) has also been prepared by Wallace via the diastereoselective conjugate addition of lithium dimethylcuprate to the appropriate 3-( $p$ tolylsulfinyl)chromone. ${ }^{17}$ The synthetic material reported by Wallace was also a crystalline solid and had a much higher specific rotation than that reported for the natural product. Since both synthetic approaches resulted in material with similar specific rotations it calls into question the optical purity of the material isolated from the natural source. There are several reasons why natural products of biosynthetic origin might not be enantiomerically pure and these have been discussed elsewhere. ${ }^{18}$ Specifically for chroman-4-ones bearing a C-2 stereocenter there is the potential for racemization via the reversible ring opening outlined earlier (Scheme 1), either in 
vivo or during isolation. ${ }^{11}$
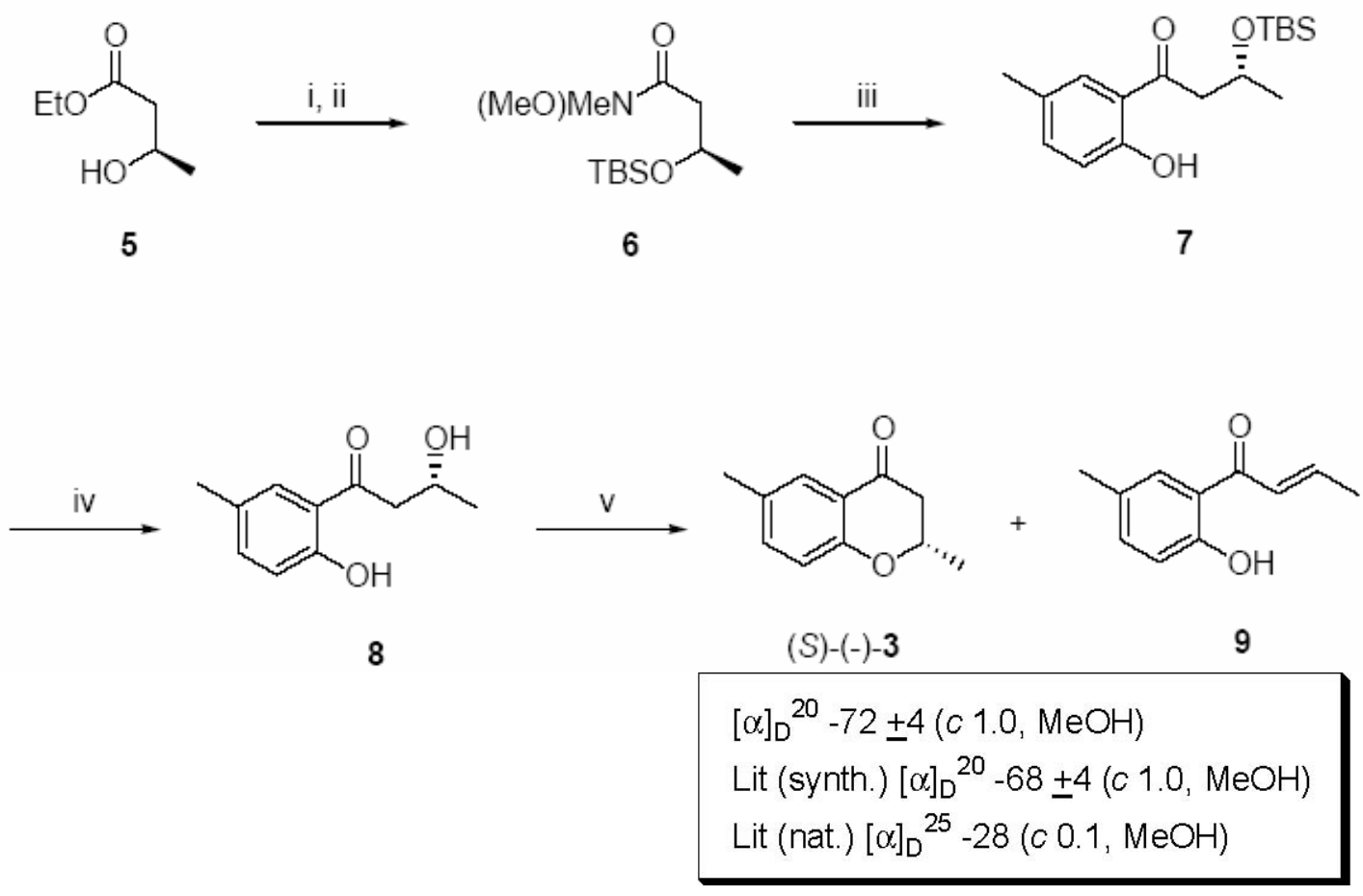

Scheme 2: Reaction conditions: (i) TBSCl, imidazole, $\mathrm{CH}_{2} \mathrm{Cl}_{2}$ (89\%); (ii) $\mathrm{MeONHMe.HCl,}$ $\mathrm{Me}^{3} \mathrm{Al}, \mathrm{CH}_{2} \mathrm{Cl}_{2}$, (74\%); (iii) 2-bromo-4-methylphenol (2 equiv.), ${ }^{\mathrm{n}} \mathrm{BuLi}$ (2 equiv.), ether, $-78^{\circ} \mathrm{C}$ to RT; (74\%); (iv) p-TsOH (10\%), THF/ $\mathrm{H}_{2} \mathrm{O}$ (9:1), $55{ }^{\circ} \mathrm{C}(81 \%)$; (v) PPh3, DEAD, THF, $0{ }^{\circ} \mathrm{C}$ (3: 81\%) (9: 7\%).

In summary, the synthesis of (S)-2,6-dimethylchroman-4-one (3) has been described employing an intramolecular Mitsunobu inversion reaction as the key step. The specific rotation of the synthetic material was larger than that described for the natural product. However, as the specific rotation of a sample prepared by a different synthetic route was also much larger than that of the natural product, the optical purity of the sample obtained from the natural source is called into question.

\section{Experimental Section}

General Procedures. Melting points were determined using a Thomas-Hoover capillary melting apparatus and are uncorrected. Elemental analyses were obtained for all new compounds. Elemental analyses were performed at Robertson Microlabs, Madison, New Jersey, U.S.A. and are within $0.4 \%$ of theoretical $\mathrm{C}, \mathrm{H}$, and $\mathrm{N} .{ }^{1} \mathrm{H}$ and ${ }^{13} \mathrm{C}$ NMR spectra were recorded in deuteriochloroform with tetramethylsilane as the internal standard on a Varian Unity $400 \mathrm{MHz}$ 
spectrometer. Coupling constants ( $J$ values) are quoted to the nearest $0.5 \mathrm{~Hz}$. Mass spectra were recorded on a VG 70SE magnetic sector mass spectrometer or a Waters Quadropole ZMDII mass spectrometer.

Organic solutions were dried using anhydrous magnesium sulfate and concentrated by rotary evaporation. Analytical thin layer chromatography (TLC) was carried out on Camlab Polygram SIL G/UV 254 plates. The chromatograms were visualized by u.v. light or suitable developing agent. Unless otherwise stated, preparative column chromatography was carried out on $60 \mathrm{H}$ silica gel (Merck 9385). Compositions of solvent mixtures are quoted as ratios of volume.

Ethyl (R)-3-(tert-butyldimethylsilyl)oxybutyrate. To a stirred solution of ethyl-(R)-3-hydroxybutyrate $5(2.0 \mathrm{~g}, 15 \mathrm{mmol})$ and imidazole $(1.36 \mathrm{~g}, 20 \mathrm{mmol})$ in dichloromethane $(75 \mathrm{~mL})$ was added tert-butyldimethylsilyl chloride $(2.4 \mathrm{~g}, 16 \mathrm{mmol})$. The mixture was stirred at room temperature overnight and the resulting white precipitate was poured into saturated aqueous ammonium chloride $(150 \mathrm{~mL})$. The mixture was extracted with dichloromethane $(3 \times 50 \mathrm{~mL})$ and the combined extracts were washed with water $(50 \mathrm{~mL})$, brine $(50 \mathrm{~mL})$, dried and evaporated. Flash chromatography of the residue, eluting with hexane - ether (19:1), gave the title compound as a colorless oil $(3.28,89 \%)$. Spectral data for this compound matched those previously reported. ${ }^{19}$

(R)-3-(tert-Butyldimethylsilyl)oxy- $N$-methoxy- $N$-methyl-butanamide (6). To a stirred suspension of $N, O$-dimethylhydroxylamine hydrochloride $(1.94 \mathrm{~g}, 20 \mathrm{mmol})$ in dichloromethane $(45 \mathrm{~mL})$ at $0{ }^{\circ} \mathrm{C}$ under nitrogen was added dropwise trimethylaluminum $(2.0 \mathrm{M}$ in toluene, $10 \mathrm{~mL}, 20 \mathrm{mmol}$ ). The reaction mixture was stirred for $20 \mathrm{~min}$. and then treated with a solution of ethyl (R)-3-(tert-butyldimethylsilyl)oxybutyrate $(2.46 \mathrm{~g}, 10 \mathrm{mmol})$ in dichloromethane $(15 \mathrm{~mL})$. The mixture was stirred at room temperature overnight and poured into saturated aqueous ammonium chloride $(150 \mathrm{~mL})$. The resulting precipitate was filtered through Celite ${ }^{\circledR}$, the filtrate extracted with dichloromethane $(3 \times 75 \mathrm{~mL})$ and the combined extracts washed with water $(50 \mathrm{~mL})$, brine $(50 \mathrm{~mL})$, dried and evaporated. Flash chromatography of the residue, eluting with hexane - ether (1:1), gave the title compound as a colorless oil (2.04 g, 78\%): vmax $1666 \mathrm{~cm}^{-1}$; $\delta \mathrm{H}(400 \mathrm{MHz}) 0.03(3 \mathrm{H}, \mathrm{s}), 0.06(3 \mathrm{H}, \mathrm{s}), 0.85(9 \mathrm{H}, \mathrm{s}), 1.20(3 \mathrm{H}, \mathrm{d}, J=6.0 \mathrm{~Hz})$, $2.33(1 \mathrm{H}, \mathrm{dd}, J=5.5$ and $14.5 \mathrm{~Hz}), 2.72-2.78(1 \mathrm{H}, \mathrm{m}), 3.16(3 \mathrm{H}, \mathrm{s}), 3.68(3 \mathrm{H}, \mathrm{s}), 4.32-4.37(1$ $\mathrm{H}, \mathrm{m}) ; \mathrm{MS} \mathrm{m} / \mathrm{z}$ (assignment, relative intensity) 262( $\left.\mathrm{M}^{+}+\mathrm{H}, 74 \%\right), 246(40), 232(20), 204(100)$, 174(20), 159(40), 130(30), 73(100); HRMS(FAB) calcd. for $\mathrm{C}_{12} \mathrm{H}_{28} \mathrm{NO}_{3} \mathrm{Si}$ 262.1838. Found 262.1838 .

(R)-1-(2-Hydroxy-5-methylphenyl)-3-(tert-butyldimethylsilyl)oxybutan-1-one (7). To a stirred solution of 2-bromo-4-methylphenol $(748 \mathrm{mg}, 4.0 \mathrm{mmol})$ in ether $(20 \mathrm{~mL})$ at $0{ }^{\circ} \mathrm{C}$ under nitrogen was added dropwise $n$-butyllithium in hexane $(2.5 \mathrm{M}, 3.2 \mathrm{~mL}, 8.0 \mathrm{mmol})$. The reaction mixture was stirred at room temperature for $2 \mathrm{~h}$, the solution cooled to $-78{ }^{\circ} \mathrm{C}$, and $6(522 \mathrm{mg}$, $2.0 \mathrm{mmol})$ in ether $(5 \mathrm{~mL})$ added dropwise. The solution was allowed to return to room temperature over $2 \mathrm{~h}$ and quenched by the dropwise addition of saturated aqueous ammonium chloride $(25 \mathrm{~mL})$. The phases were separated and the aqueous layer extracted with ether $(3 \mathrm{x}$ 
$25 \mathrm{~mL})$, combined and washed with water $(30 \mathrm{~mL})$, brine $(30 \mathrm{~mL})$, dried and evaporated. Flash chromatography of the residue, eluting with hexane - ether $(3: 1)$, gave the title compound as a colorless oil (455 mg, 74\%): $v_{\max } 1637 \mathrm{~cm}^{-1}$; $\delta_{\mathrm{H}}(400 \mathrm{MHz})-0.09(3 \mathrm{H}, \mathrm{s}), 0.03(3 \mathrm{H}, \mathrm{s}), 0.78(9$ $\mathrm{H}, \mathrm{s}), 1.27(3 \mathrm{H}, \mathrm{d}, J=6.0 \mathrm{~Hz}), 2.30(3 \mathrm{H}, \mathrm{s}), 2.81(1 \mathrm{H}, \mathrm{dd}, J=5.0$ and $14.5 \mathrm{~Hz}), 3.28(1 \mathrm{H}$, dd, $J=7.5$ and $14.5 \mathrm{~Hz}), 4.39-4.47(1 \mathrm{H}, \mathrm{m}), 6.86(1 \mathrm{H}, \mathrm{d}, J=8.0 \mathrm{~Hz}), 6.96(1 \mathrm{H}, \mathrm{d}, J=8.0 \mathrm{~Hz})$, $7.57(1 \mathrm{H}, \mathrm{s}), 12.23(1 \mathrm{H}, \mathrm{s}) ; \delta \mathrm{C}(100 \mathrm{MHz})-5.16,-4.73,17.85,20.47,24.44,25.62,47.80$, $66.33,118.04,119.75,127.78,130.67,137.41,160.56,205.53 ; \mathrm{MS} \mathrm{m} / \mathrm{z}$ (assignment, relative intensity) 309( $\left.\mathrm{M}^{+}+\mathrm{H}, 100 \%\right)$; Anal. $\mathrm{C}_{17} \mathrm{H}_{28} \mathrm{O}_{3}$ Si requires: C, 66.19; H, 9.15. Found: $\mathrm{C}, 66.21$; $\mathrm{H}, 9.16 \%$.

(R)-3-Hydroxy-1-(2-hydroxy-5-methylphenyl)butan-1-one (8). To a stirred solution of 7 (308 $\mathrm{mg}, 1.0 \mathrm{mmol})$ in THF $(9 \mathrm{~mL})$ and water $(1 \mathrm{~mL})$ was added $p$-toluenesulfonic acid $(19 \mathrm{mg}, 0.1$ mmol). The solution was heated to $55{ }^{\circ} \mathrm{C}$ for $12 \mathrm{~h}$, cooled and poured into saturated aqueous sodium bicarbonate $(15 \mathrm{~mL})$. The mixture was extracted with ethyl acetate $(3 \times 15 \mathrm{~mL})$ and the combined extracts washed with brine $(25 \mathrm{~mL})$, dried and evaporated. Flash chromatography of the residue, eluting with hexane - ether (1:1), gave the title compound as a colorless oil (156 mg, 81\%): $v_{\max } 3542-3295 \mathrm{br}, 1631 \mathrm{~cm}^{-1} ; \delta_{\mathrm{H}}(400 \mathrm{MHz}) 1.28(3 \mathrm{H}, \mathrm{d}, J=6.0 \mathrm{~Hz}), 2.28(3 \mathrm{H}, \mathrm{s}), 3.08-$ $3.10(2 \mathrm{H}, \mathrm{m}), 3.17$ (1 H, brs), 4.35-4.43 (1 H, m), $6.85(1 \mathrm{H}, \mathrm{d}, J=8.0 \mathrm{~Hz}), 7.26(1 \mathrm{H}, \mathrm{d}, J=8.0$ $\mathrm{Hz}), 7.47(1 \mathrm{H}, \mathrm{s}), 11.90(1 \mathrm{H}, \mathrm{s}) ; \delta \mathrm{C}(100 \mathrm{MHz})$ 20.40, 22.48, 46.25, 63.77, 118.24, 118.99, 128.11, 129.60, 137.75, 160.32, 206.05; MS m/z (assignment, relative intensity) $195\left(\mathrm{M}^{+}+\mathrm{H}\right.$, $100 \%$ ); Anal. $\mathrm{C}_{11} \mathrm{H}_{14} \mathrm{O}_{3}$ requires: $\mathrm{C}, 68.02 ; \mathrm{H}, 7.27$. Found: $\mathrm{C}, 67.91 ; \mathrm{H}, 7.25 \%$.

(S)-2,6-Dimethylchroman-4-one (3). A solution of triphenylphosphine (131 mg, $0.5 \mathrm{mmol}$ ) and diethyl azodicarboxylate $(88 \mathrm{mg}, 0.5 \mathrm{mmol})$ in THF $(3 \mathrm{~mL})$ at $0{ }^{\circ} \mathrm{C}$ was stirred for $15 \mathrm{~min}$ and then added dropwise to a solution of $8(97 \mathrm{mg}, 0.5 \mathrm{mmol})$ in THF $(3 \mathrm{~mL})$ at $0{ }^{\circ} \mathrm{C}$. The reaction mixture was stirred for $1 \mathrm{~h}$ at $0{ }^{\circ} \mathrm{C}$ and the volatiles removed by evaporation. Flash chromatography of the residue, eluting with hexane - ether (1:1 and then 1:2), gave the title compound as a colorless solid, $\mathrm{mp} 77{ }^{\circ} \mathrm{C}(71 \mathrm{mg}, 81 \%):[\alpha]_{\mathrm{D}}{ }^{20}=-72+4(c 1.0, \mathrm{MeOH}) ; v_{\max }$ $1682,1621,1576 \mathrm{~cm}^{-1} ; \delta \mathrm{H}(400 \mathrm{MHz}) 1.48(3 \mathrm{H}, \mathrm{d}, J=6 \mathrm{~Hz}), 2.28(3 \mathrm{H}, \mathrm{s}), 2.62-2.65(2 \mathrm{H}, \mathrm{m})$, 4.50-4.56 (1H, m), $6.84(1 \mathrm{H}, \mathrm{d}, J=8.5 \mathrm{~Hz}), 7.26(1 \mathrm{H}, \mathrm{d}, J=8.5 \mathrm{~Hz}), 7.65(1 \mathrm{H}, \mathrm{s}) ; \delta \mathrm{C}(100$ MHz) 20.31, 20.91, 44.57, 74.15, 117.58, 120.34, 126.43, 130.53, 136.97, 159.69, 192.66; Anal. $\mathrm{C}_{11} \mathrm{H}_{12} \mathrm{O}_{2}$ requires: $\mathrm{C}, 74.98 ; \mathrm{H}, 6.86$. Found: $\mathrm{C}, 75.09 ; \mathrm{H}, 6.76 \%$.

\section{References and notes}

1. (a) Dean, F.M., Naturally Occurring Oxygen Ring Compounds, Butterworths: London, 1963. (b) Ellis, G.P.; Lockhart, I.M., Chromans and Tocopherols, Wiley: New York, 1977.

(c) Saengchantara, S.T.; Wallace, T. W. Nat. Prod. Rep. 1986, 3, 465. (d) Geen, G.; Evans, J. M.; Vong, A. K. Comprehensive Heterocyclic Chemistry II; McKillop, A.; Ed.; Pergamon: Oxford, 1996; Vol. 5, pp 469.

2. Chandler, I.M.; McIntyre, C.R.; Simpson, T.J. J. Chem. Soc., Perkin Trans. 1 1992, 2271. 
3. For examples see: (a) Erdtman, H. Svensk Kem. Tidskr. 1944, 56, 95; (b) Lindstedt, G. Acta Chem. Scand. 1950, 4, 1042; (c) Wollenweber, E. Phytochemistry 1982, 20, 1462; (d) Jaipetch, T.; Reutrakul, V.; Tuntiwachwuttikul, P.; Santisuk, T. Phytochemistry 1983, 22, 625; (e) Haberlein, H.; Tschiersch, K-P. Biochemical Systematics and Ecology 1998, $26,97$.

4. Comey, N.; Hook, I.; Sheridan, H.; Walsh, J.; James, P. J. J. Nat. Prod. 1997, 60, 148.

5. For some recent approaches to vitamin E see: (a) Harada, T.; Hayashiya, T.; Wada, I.; Iwaake, N.; Oku, A. J. Am. Chem. Soc. 1987, 109, 527; (b) Inoue, S.; Ikeda, H.; Sato, S.; Horie, K.; Ota, T.; Miyamoto, O.; Sato, K. J. Org. Chem. 1987, 52, 5495; (c) Hubsher, J.; Barner, R. Helv. Chem. Acta 1990, 73, 1068; (d) Mizuguchi, S.; Suzuki, T.; Achiwa, K. Synlett 1996, 743; (e) Tietze, L.F.; Gorlitzer, J. Synthesis 1997, 877.

6. (a) Saengchantara, S.T.; Wallace, T.W. J. Chem. Soc., Chem. Commun., 1986, 1592; (b) Saengchantara, S.T.; Wallace, T.W. Tetrahedron 1990, 46, 6553. (c) For a recent application to the synthesis of a flavanone, see Solladié, G.; Gehrold, N.; Maigan, J. Tetrahedron: Asymmetry 1999, 10, 2739.

7. Rama Rao, A.V.; Gaitonde, A.S.; Prakash, K.R.C.; Prahlada Rao, S. Tetrahedron Lett. 1994, 35, 6347.

8. (a) Sato, K.; Tomoyuki, Y.; Mitsuru, S.; Shishido, K. J. Org. Chem. 2001, 66, 309; (b) Birkett, M. A.; Knight, D. W.; Little, P. B.; Mitchell, M. B. Tetrahedron 2000, 56, 1013.

9. (a) Wipf, P.; Weiner, W. S. J. Org. Chem. 1999, 64, 5321; (b) Johannes, C. W.; Visser, M. S.; Weatherhead, G. S.; Hoveyda, A. H. J. Am. Chem. Soc. 1998, 120, 8340 and references cited therein.

10. Trost, B. M.; Toste, F. D. J. Am. Chem. Soc. 1998, 120, 9074.

11. (a) Akuamoah, R. K.; Brown, P. E.; Marcus, W. Y.; Steel, J. E. J. Chem. Soc., Perkin Trans. 1 1995, 197; (b) Anastasis, P; Brown, P. E. J. Chem. Soc., Perkin Trans. 1 1983, 197.

12. (a) Hodgetts, K. J. Tetrahedron Lett. 2000, 41, 8655; (b) Hodgetts, K. J. Tetrahedron Lett. 2001, 42, 3763.

13. Purchased from Aldrich, $99 \%$ e.e. by GLC.

14. Nahm, S.; Weinreb, S. M. Tetrahedron Lett. 1981, 22, 3815.

15. Mitsunobu, O. Synthesis 1981, 1.

16. Baldwin, J. E.; Thomas, R. C.; Kruse, L. I.; Silberman, L. J. Org. Chem. 1977, 42, 3846.

17. Hodgetts, K. J.; Maragkou, K. I.; Wallace, T. W.; Wootton, R. C. R. Tetrahedron 2001, 57, 6793.

18. Rautenstrauch, V.; Lindstrom, M.; Bourdin, B.; Currie, J.; Oliveros, E. Helv. Chim. Acta 1993, 76, 607.

19. Ireland, R. E.; Wardle, R. B. J. Org. Chem. 1987, 52, 1780. 